\title{
DGCR8 Gene
}

National Cancer Institute

\section{Source}

National Cancer Institute. DGCR8 Gene. NCI Thesaurus. Code C92663.

This gene plays a role in microRNA processing. 